УдК 347.965.982

\author{
Н. М. Бакаянова
}

\title{
ФОРМИ ОРГАНІЗАЦІЇ АДВОКАТСЬКОЇ ДІЯЛЬНОСТІ ТА ЇХ ПРАВОВЕ РЕГУЛЮВАННЯ
}

Постановка проблеми. Надзвичайно важливим аспектом організації адвокатури є визначення форм організації адвокатської діяльності, які б дозволяли належним чином реалізувати завдання з захисту прав, свобод та законних інтересів фізичних та юридичних осіб.

Законодавство про адвокатуру та адвокатську діяльність використовує такий термін, як «організаційні (організаційно-правові) форми адвокатської діяльності», проте не містить визначення цього поняття. Аналіз правової думки також свідчить про те, що сутності організаційних (організаційно-правових) форм адвокатської діяльності, їх характеристикам у науці не приділено багато уваги. Однак без їх визначення досить складно знайти розв'язання проблем, які виникають у сфері регулювання організації діяльності адвокатури та здійснення адвокатської діяльності.

У світлі реформи законодавства про адвокатуру та адвокатську діяльність дослідження поняття форми організації адвокатської діяльності набуває особливої актуальності.

Аналіз останніх досліджень та публікацій. Теоретичні і практичні проблеми інституту адвокатури вивчалися М.Р. Аракеляном, Т.В. Варфоломеєвою, Є.В. Васьковським, Т.Б. Вільчик, С.В. Гончаренко, І.Ю. Гловацьким, І.В. Голованем, Ю.М. Грошевим, О.Л. Жуковською, Я.П. Зейканом, Д.В. Кухнюком, О.Д. Святоцьким, Л.В. Тацій, Д.П. Фіолевським, С.Я. Фурсою, П.В. Хотенцем та ін.

Питання організаційних форм адвокатської діяльності грунтовно досліджувала А.В. Іванцова в дисертації «Організаційні форми діяльності адвокатури» [1], проте питання, наскільки прийнятним є використання терміна «організаційно-правова форма адвокатської діяльності», зазначеній роботі не розглядалося.

Окремі аспекти організаційно-правових форм в адвокатурі розкрито в статтях К.Г. Книгіна [2; 3], зокрема, застосовано порівняльний метод у дослідженні сучасних організаційно-правових форм адвокатської діяльності 3 тими їх формами, які існували до набрання чинності діючим Законом «Про адвокатуру та адвокатську діяльність». 
Проте поняття організаційно-правової форми адвокатської діяльності в юридичній літературі комплексно не висвітлювалося, що обумовлює необхідність грунтовних досліджень.

Метою статті є з'ясування змісту поняття «організаційно-правова форма адвокатської діяльності», визначення дискусійних аспектів його застосування в законодавстві та науковій літературі, розробка пропозиції щодо удосконалення термінології законодавства про адвокатуру та адвокатську діяльність.

Виклад основного матеріалу. Терміни «організаційно-правова форма адвокатської діяльності» та «організаційна форма адвокатської діяльності» використано в Законі «Про адвокатуру та адвокатську діяльність», вони також $є$ досить поширеними у науковій літературі. Так, згідно з ч. 3 ст. 4 Закону «Про адвокатуру та адвокатську діяльність» адвокат може здійснювати адвокатську діяльність індивідуально або в організаційно-правових формах адвокатського бюро чи адвокатського об'єднання (організаційні форми адвокатської діяльності).

3 ч. 3 ст. 4 Закону «Про адвокатуру та адвокатську діяльність» випливає, що поняття організаційних (організаційно-правових) форм адвокатської діяльності лежить у площині видів суб'єктів (адвоката, адвокатського бюро, адвокатського об'єднання) цієї діяльності. Тому цілком логічно припустити, що організаційні форми адвокатської діяльності повинні були б відображати певні типи, варіанти побудови адвокатської діяльності, що різняться один від одного різними організаційними аспектами, які характеризують тих чи інших суб'єктів адвокатської діяльності. Проте така логічна конструкція потребує аналізу, так само, як і вживання іншого поняття - «форми здійснення адвокатської діяльності [4, с. 618].

Поняття «форма» походить від латинського «forma», що означає зовнішній вигляд, зовнішній вияв, зовнішне вираження. Форма - це обриси, контури, зовнішні межі предмета, що визначають його зовнішній вигляд, конфігурація; тип, будова, спосіб організації чого-небудь; видимість, зовнішній бік чого-небудь, що не відображає суті справи; спосіб здійснення, виявлення будь-якої дії; суворо встановлений порядок у будь-якій справі [5, с. 665].

Такий зміст поняття «форма» говорить про об’єктивність ії запровадження та існування. Однак тут слід відзначити, що організаційна форма адвокатури має не тільки удосконалюватися відповідно до сучасних потреб, а й передбачати шляхи розвитку. У зв'язку із цим доцільно використовувати поняття «модель», що символізуватиме не сталу «конструкцію», а здатну до видозмінювання організаційну структуру.

У праві питання організаційно-правової форми використовується, зокрема, стосовно господарської діяльності чи щодо організаційно-правової форми юридичної особи.

Так, наприклад, зазначається, що організаційно-правовою формою господарської діяльності є свого роду конституція, модель, основа, на підставі якої здійснюється господарська діяльність суб'єкта господарювання [6, с. 107]. Організаційно-правова форма є визначальною для характеристики об’єкта 
прав, обов'язків, меж відповідальності конкретного суб'єкта підприємницької діяльності [7, с. 185-186]. 3 організаційно-правовою формою пов'язані питання формування майна, організаційної структури, взаємовідносини 3 учасниками та учасників один із одним; відповідальність учасників перед юридичною особою та юридичної особи перед іï учасниками та іншими суб’єктами підприємницького обігу [8, с. 162-163]. У правовій літературі під час дослідження організаційно-правової форми юридичної особи висловлено також думку, що поняття організаційно-правової форми є синонімом виду юридичної особи [9, с. 26-28; 10, с. 18], їх поділу за окремими критеріями, пов'язаними з організацією юридичної особи.

На думку А. В. Іванцової, сучасна організаційна структура адвокатури України проявляється через діяльність: (а) адвокатських утворень (адвокати й адвокатські об'єднання); (б) професійних об’єднань (організацій) адвокатів (спілки та асоціаціі) [1, с. 11]. Проте, як зазначає С.О. Іваницький, поняття структури адвокатури часто використовується замість поняття системи адвокатури, хоча за своїм змістом структура $€$ формою розміщення елементів системи [11, с. 460-461].

Повертаючись до поняття форми, очевидним $є$ те, що поняття форми загалом та поняття організаційної форми зокрема $є$ багатозначними, але в контексті дослідження організації адвокатської діяльності прийнятним $€$ значення форми як типу, будови, способу організації адвокатської практики.

Поняття адвокатської діяльності як незалежної професійної діяльності адвоката означає, що цю діяльність безпосередньо здійснює виключно адвокат. Хоча адвокатські бюро та адвокатські об'єднання виступають стороною договору про надання правової допомоги, вони безпосередньо не є суб'єктами здійснення адвокатської діяльності. Адвокатську діяльність здійснюють адвокати, які є працюють у складі адвокатського об’єднання або бюро. Адвокатські бюро та адвокатські об'єднання лише визначають організацію діяльності адвокатів. У зв'язку із цим застосоване в Законі словосполучення «організаційні (організаційно-правові) форми адвокатської діяльності» спотворено відображає той об’єкт, який є предметом видового поділу в характеристиці організаційних форм, що існують в адвокатурі.

У понятті «організаційна форма адвокатської діяльності» предметом поділу виступає адвокатська діяльність з надання правової допомоги, а в понятті «форма організації адвокатської діяльності» - саме організація цієї діяльності, що є більш точним.

Застосований у Законі підхід щодо формулювання досліджуваного поняття саме як «організаційні форми адвокатської діяльності» очевидно грунтується на окремих висловлених у науці думках. Так, зокрема, С.Д. Гусарєв, аналізуючи організаційні форми юридичної діяльності, зазначив, що це реальні інституції, установи, органи, філії, регіональні представництва, а разом з ними приміщення, персонал, конкретна територія - тобто ряд параметрів інституційного характеру, що розглядаються як необхідні формалізовані атрибути діяльності. Законодавець оперує термінами «система органів», «підрозділи», «організація», «установа», «з”ізд», «бюро», 
«контора», «об'єднання», «спілка» «асоціація», які в реальній дійсності є зовнішнім проявом змісту - формою діяльності в ії організаційному аспекті [12, с. 106]. Проте висловлена точка зору є дискусійною.

Зовнішнім проявом юридичної діяльності загалом та адвокатської діяльності зокрема є ті дії, які вчиняє суб’єкт цієї діяльності. Зовнішнім проявом адвокатської діяльності будуть дії адвоката, пов'язані з наданням правової допомоги. Зазначені С.Д. Гусарєвим терміни хоча й характеризують організацію юридичної діяльності, проте більше відображають вид суб'єкта цієї діяльності, його організаційно-правову форму або ж навіть форму саме організації цієї діяльності, а не зміст діяльності як об'єкта загалом.

У зв'язку із цим очевидно, що під час дослідження питань організації адвокатської діяльності необхідно вести мову не про «організаційні форми адвокатської діяльності» або «форми здійснення адвокатської діяльності», а, принаймні, про «форми організації адвокатської діяльності». Таке поняття матиме більш правильне змістове навантаження, грунтовно та адекватно відображатиме ті характеристики, які властиві саме існуючим в адвокатурі організаційно-правовим формам.

Висновки. Закріплене в ч. 3 ст. 4 Закону «Про адвокатуру та адвокатську діяльність» поняття організаційної (організаційно-правової) форми саме адвокатської діяльності спотворено відображає той об'єкт, який є предметом видового поділу в характеристиці організаційних форм, що існують в адвокатурі. У понятті «організаційна форма адвокатської діяльності» предметом поділу виступає адвокатська діяльність з надання правової допомоги, а в понятті «форма організації адвокатської діяльності» - саме організація цієї діяльності, що є більш точним. Із цих підстав доцільно замінити термін «організаційні форми адвокатської діяльності» на «форми організації адвокатської діяльності» в законодавстві про адвокатуру та адвокатську діяльність.

Подальші дослідження форм організації адвокатської діяльності доцільно спрямувати на визначення особливостей кожної форми організації адвокатської діяльності, специфіки індивідуальної адвокатської діяльності, організації роботи в адвокатських бюро та адвокатських об'єднаннях.

\section{Література}

1. Іванцова А.В. Організаційні форми діяльності адвокатури : автореф. дис. на здобуття наук. ступеня канд. юрид. наук : спец. 12.00.10 / А.В. Іванцова ; Нац. юрид. акад. України ім. Я. Мудрого. - Харків, 2010. - 20 с.

2. Книгін К.Г. Організаційно-правові форми надання правової допомоги адвокатом за чинним законодавством України / К.Г. Книгін // Актуальні проблеми держави і права. - 2014. Вип. 72. - С. 417-423. - [Електронний ресурс]. - Режим доступу : http://nbuv.gov.ua/ UJRN/apdp_2014_72_62.

3. Книгін К.Г. Суб'єкти договору надання правових послуг адвокатом / К.Г. Книгін // Актуальні проблеми держави і права. - 2012. - Вип. 63. - С. 480-489. - [Електронний ресурс]. Режим доступу : http:/ / nbuv.gov.ua/UJRN/apdp_2012_63_74.

4. Адвокатура України : підручник. У 2 кн. Кн. 1. Організація адвокатури (з практикумом) / за заг. ред. С.Я. Фурси та Н.М. Бакаянової. - 2-ге вид., допов. і переробл. - Київ : Алерта, 2016. -864 c

5. Новий тлумачний словник української мови. У 3 т. Т. 3. П-Я / уклад.: В.В. Яременко, О.М. Сліпушко. - 2-ге вид. - Київ : АКОНІТ, 2004. - 862 с. 
6. Коваль І.Ф. Щодо застосування поняття «організаційно-правова форма» в Господарському кодексі України / І.Ф. Коваль, Н.В. Щербакова // Форум права. - 2015. - № 3. C. 107-112. - [Електронний ресурс]. - Режим доступу : http://nbuv.gov.ua/j-pdf/FP_index. htm_2015_3_21.pdf.

7. Саніахметова Н.О. Підприємницьке право : Суб’єкти підприємництва. Кредитування. Оренда. Лізинг. Зовнішньоекономічна діяльність. Антимонопольне законодавство. Захист від недобросовісної конкуренції. Реклама : навч. посіб. / Н.О. Саніахметова. - Київ : А.С.К., 2002. - 704 c.

8. Корпоративное право : учеб. курс : учебник / отв. ред. И.С. Шиткина. - Москва : KHO-PУC, 2011. - $1120 \mathrm{c}$.

9. Жаринов С.Е. Организационно-правовые формы коммерческих организаций: парадоксы Гражданского кодекса / С.Е. Жаринов / / Законодательство. - 1998. - № 12. - С. 26-28.

10. Кучеренко I.M. Організаційно-правові форми юридичних осіб приватного права : монографія / I.M. Кучеренко ; Ін-т держави і права ім. В.М. Корецького НАН України. - Київ, 2004. -328 c

11. Іваницький С.О. Теоретичні основи організації адвокатури в Україні: принципи та система : монографія / С.О. Іваницький. - Київ : Інтерсервіс, 2017. - 800 с.

12. Гусарєв С.Д. Юридична діяльність: методологічні та теоретичні аспекти / С.Д. Гусарєв. Київ : Знання, 2005. - 375 с.

\section{Анот а ц і я}

Бакаянова Н. М. Форми організації адвокатської діяльності та їх правове регулювання. - Стаття.

У статті досліджується поняття організаційної (організаційно-правової) форми адвокатської діяльності. Автор доводить, що поняття організаційної (організаційно-правової) форми саме адвокатської діяльності спотворено відображає той об’єкт, який є предметом видового поділу при характеристиці організаційних форм, що існують в адвокатурі. У понятті «організаційна форма адвокатської діяльності» предметом поділу виступає адвокатська діяльність з надання правової допомоги, а в понятті «форма організації адвокатської діяльності» саме організація цієї діяльності, що є більш точним. Із цих підстав доцільно замінити термін «організаційні форми адвокатської діяльності» на термін «форми організації адвокатської діяльності» в ч. 3 ст. 4 Закону України «Про адвокатуру та адвокатську діяльність».

Ключові слова: адвокатура, адвокатська діяльність, організаційна форма адвокатської діяльності, адвокатське бюро, адвокатське об’єднання.

\section{Анно т а ция}

Бакаянова Н. М. Формы организации адвокатской деятельности и их правовое регулирование. - Статья.

В статье исследуется понятие организационной (организационно-правовой) формы адвокатской деятельности. Автор доказывает, что понятие организационной (организационно-правовой) формы адвокатской деятельности искаженно отображает тот объект, который является предметом деления на виды при характеристике организационных форм, существующих в адвокатуре. В понятии «организационная форма адвокатской деятельности» предметом деления выступает адвокатская деятельность по оказанию правовой помощи, а в понятии «форма организации адвокатской деятельности» - именно организация этой деятельности, что является более точным. На этом основании целесообразно заменить термин «организационные формы адвокатской деятельности» на термин «формы организации адвокатской деятельности» в ч. 3 ст. 4 Закона Украины «Об адвокатуре и адвокатской деятельности».

Ключевые слова: адвокатура, адвокатская деятельность, организационная форма адвокатской деятельности, адвокатское бюро, адвокатское объединение. 


\section{S u m m a r y}

Bakaianova N. M. Forms of organization of advocacy activity and its legal regulation. Article.

The article deals with the concept of organizational (organizational and legal) form of advocacy. The author proves that the notion of an organizational (organizational and legal) form of a lawyer's activity is distortingly reflects the object which is the subject of a distinctive division in characterizing the organizational forms existing in the advocacy. In the notion of «organizational form of advocacy» the subject of division is the lawyer's activity in providing legal aid, and in the notion of «form of organization of advocacy» - the very organization of this activity, which is more precise. For these reasons, it is expedient to replace the term «organizational forms of advocacy» with «forms of organization of advocacy» in the Part 3 of Art. 4 of the Law of Ukraine «On Advocacy and Advocacy».

Key words: advocacy, advocate activity, organizational form of advocacy, law office, advocate association. 